JARES, Vol. 4 No. 2 September, 2019; p-ISSN: 2502-826X; e-ISSN: 2503-1163

Copyrights@ Balitar Islamic University, Blitar, Indonesia;

https://ejournal.unisbablitar.ac.id/index.php/jares

Citation: Elvianita Martanti, D., \& Suprayitno , H. (2019). NDERES PROFIT SHARING MODEL

ON THE BROWN SUGAR FARMERS IN NGLEGOK DISTRICT BLITAR REGENCY. JARES

(Journal of Academic Research and Sciences), 4(2), 39-50. https://doi.org/10.35457/jares.v4i2.841

\title{
“NDERES” PROFIT SHARING MODEL ON THE BROWN SUGAR FARMERS IN NGLEGOK DISTRICT BLITAR REGENCY
}

\author{
${ }^{1}$ Diana Elvianita Martanti, ${ }^{2}$ Hery Suprayitno \\ Program Studi Akuntansi, Universitas Islam Blitar \\ Email: ${ }^{1}$ dianaelvianitamartanti@unisbablitar.ac.id, ${ }^{2}$ herysuprayitno@unisbabalitar.ac.id
}

\begin{abstract}
Profit sharing is a mutually beneficial collaboration between two or more people on mutual agreement. The purpose of this study is to find out the profit sharing model "nderes" for brown sugar farmers in Nglegok Blitar sub-district. One area in Blitar regency which is a producer of brown sugar is Nglegok Subdistrict. This is because Nglegok village has fertile land and there are still many coconut trees that grow up. Therefore, many Ngelgok subdistrict residents who utilize the results of coconut tree sap to be made into brown sugar even though to take coconut palm juice the risk is quite large because it is not impossible to have an accident when taking the sap, such as falling from coconut trees and others. Because of the large risk, many owners of coconut trees do not dare to climb by themselves, so in order to obtain additional income they work together with other people who dare to take the sap water with a profit sharing system. This research method used a qualitative approach with the interview method to the beneficiary, coconut tree owners and "legen" cookers in Nglegok sub-district Blitar Regency. The results of this study produce various concepts of cooperation, namely based on the results of "nderes" in the form of ounces and profit sharing based on the day.
\end{abstract}

Keywords: Profit Sharing Model, Nderes, Brown Sugar

\section{INTRODUCTION}

This transaction phenomenon is seen in the community, one of them is the group of red sugar farmers in Blitar Regency. The accounting system applied in the community of red sugar farmers in Blitar Regency still uses the traditional model.

The function of accounting in the manner of a local wesdom was to provide qualitative and quantitative information (mauliyah , masrunik, \&; wahyudi, 2017,) especially having the character about financial entity economic meanwhile expected to increase a lot of useful information in the manufacture of economic decisions in making choice between come up with an alternative appropriate effort with a certain area. Each area have a model in the transactions of accounting. Even though, a traditional accounting system method cannot be proposed in a generalization, but, it can run well and it has been recognized by the community, one of this model is the profit-sharing system ( hidayat, huda , \&; mauliyah notes to be so performed , 2019 ) .Profit-sharing system is a system in where an agreement or joint the agreement is carried out in conducting business activities .In 
JARES, Vol. 4 No. 2 September, 2019; p-ISSN: 2502-826X; e-ISSN: 2503-1163

Copyrights@ Balitar Islamic University, Blitar, Indonesia;

https://ejournal.unisbablitar.ac.id/index.php/jares

Citation: Elvianita Martanti, D., \& Suprayitno , H. (2019). NDERES PROFIT SHARING MODEL ON THE BROWN SUGAR FARMERS IN NGLEGOK DISTRICT BLITAR REGENCY. JARES (Journal of Academic Research and Sciences), 4(2), 39-50. https://doi.org/10.35457/jares.v4i2.841 business there is a promise of sharing the result of the profits to be obtained between the two or more parties.

Changes in the name of the system for the results may be due to differences in time and place of naming. The procedure for the sharing system in each region is different. Likewise, nderes profit sharing system in Sanan Dayu. The economic activity in Sanan Dayu community in making brown sugar has been a tradition for generations. Nderes is a process or profession of the community in making brown sugar. Profit-sharing is an agreement of profit and/or loss sharing with a certain amount of a certain amount of funds between the owner of the fund and the party using the funds (Hidayat et al., 2019)

Meanwhile, according to Abdurrahman (2001: 192) defines that profit sharing is the amount of income received by customers based on the giving of profits generated by the bank, profit sharing depends on the profits of the project being carried out, if it does not get a profit then the loss is borne by both parties, namely the bank and the customer

From the three definitions of profit sharing above, the researcher conclude that profit sharing is the sharing of profit and / or loss that has been mutually agreed upon where if it gets a profit, it will be shared fairly and if the loss will also be borne by both parties concerned. The activity is a strategic management in community economic activities (Huda \& Martanti, 2018).

According to Wahyuningsih (2011) the profit sharing agreement system is a form of cooperation carried out by the community long ago. The production sharing agreement was carried out by two parties, namely between the owner of a coconut tree and a penderes. According to Irmayanti (2010: 49), the results of management will be divided according to the agreement of each party and general habits that apply in an area or system that applies in the community. Custom influences the habits of the community directly; it means that custom in a certain area influences the agricultural profit sharing system of that region. Another thing that interest for researchers in the profit-sharing system is the agreement made by both parties, especially the agreement related to the issue of time and operational costs. The initial contract was made between the owner of a coconut tree, a sapper and a coconut tree climber (penderes) in providing clarity when the cooperation agreement will end.

Furthermore, cooperation between coconut tree owners, extract coconut water cookers and penderes can be based on the results of the production of brown sugar or based 
JARES, Vol. 4 No. 2 September, 2019; p-ISSN: 2502-826X; e-ISSN: 2503-1163

Copyrights@ Balitar Islamic University, Blitar, Indonesia;

https://ejournal.unisbablitar.ac.id/index.php/jares

Citation: Elvianita Martanti, D., \& Suprayitno , H. (2019). NDERES PROFIT SHARING MODEL ON THE BROWN SUGAR FARMERS IN NGLEGOK DISTRICT BLITAR REGENCY. JARES (Journal of Academic Research and Sciences), 4(2), 39-50. https://doi.org/10.35457/jares.v4i2.841 on extract coconut water. Meanwhile, according to Jusmaliani (2005) an agreement is an agreement of two parties that protect the common interest. In this context it is no longer two parties but three parties who have a common interest, between these three parties who will get a share in accordance with the mutual agreement. This agreement has been felt and accepted by brown sugar farmers by living comfortably and not in conflict with each other in receiving the profit sharing system.

The abundant production of brown sugar contributes to the brown sugar industry which is widely developed in Nglegok District. It is inseparable from the role of brown sugar farmers in this region because they are willing to risk their safety to take extract coconut water from the top of the coconut tree which is the material for making brown sugar. They are willing to climb coconut trees every day without any safety device to get extract coconut water which will be cooked to be made into brown sugar. Whereas to take extract coconut water has a considerable risk because it is not impossible that an accident might occur while taking it, such as falling from coconut trees and so on. Because of the magnitude of the risk, many coconut tree owners do not dare to climb on their own, so in order to obtain additional income, they work together with others who dare to take the extract coconut water from the profit sharing system. The profit sharing system that applies in Sanan Dayu Village is 2 kinds, namely the tampan(tumbler) profit sharing and ounce profit sharing. Profit sharing that is often used in Sanan Daayu is tampan(tumbler) profit sharing.

Production of brown sugar can be done every day as long as the coconut tree can still produce the extract water. This means that the climber must climb a coconut tree every day to collect the extract water. Even to get maximum results they have to grind the coconut tree twice in each day in the morning and evening. Climbing in the morning to take the extract water while climbing in the afternoon to cut the coconut flower so that the result of extract water is better.

This research has relevance between previous researches, including:

a. Based on Afriyanti Ansyar's research (2014: 54) entitled "Analysis of the Difference in Income of Farmers Owning Cultivators and Cultivating Farmers in the Coconut Sugar Business in Purbosari Village, West Seluma District, Seluma Regency" concluded that 
JARES, Vol. 4 No. 2 September, 2019; p-ISSN: 2502-826X; e-ISSN: 2503-1163

Copyrights@ Balitar Islamic University, Blitar, Indonesia;

https://ejournal.unisbablitar.ac.id/index.php/jares

Citation: Elvianita Martanti, D., \& Suprayitno , H. (2019). NDERES PROFIT SHARING MODEL ON THE BROWN SUGAR FARMERS IN NGLEGOK DISTRICT BLITAR REGENCY. JARES

(Journal of Academic Research and Sciences), 4(2), 39-50. https://doi.org/10.35457/jares.v4i2.841

the income of the owner and cultivating farmer was no income difference that was relatively same as the income significant level.

b. Based on the research of Siti Khotimah et al (2014: 52) entitled "Analysis of Coconut Sugar Farmer Income and Its Contribution to Family Income in Lojejer Village, Wuluhan Subdistrict, Jember Regency" concluded that there were differences in the income of the farmer of coconut sugar in the profit sharing of sugar and extract coconut water production. Factors that significantly affect the income of farmer coconut sugar in Lojejer Village, Wuluhan Subdistrict, Jember Regency are: fuel costs (Rp / month), additional material costs ( $\mathrm{Rp} /$ month), selling price ( $\mathrm{Rp} / \mathrm{kg}$ ), amount production $(\mathrm{kg})$, labor costs (Rp / month) and profit sharing system used.

Based on the statement above, the researcher intends to conduct a study with the title "Nderes Profit Sharing Model" on the Brown Sugar Farmers in Nglegok District, Blitar Regency"

\section{RESEARCH METHOD}

This research was conducted in Sanan Dayu village RT 04 RW 03, Nglegok District, Blitar Regency. This research was conducted in 2019. This research was conducted because researchers often heard the term nderes in other areas about a farming system carried out by brown sugar farmers, one of which produced a profit-sharing system. This study illustrates the profit sharing model for brown sugar farmers in Nglegok District.

Sugiyono (2009: 2) explained that the research method is basically a scientific way to obtain data with specific purposes and uses. This research uses a qualitative method using a phenomenological approach. Qualitative research is a research procedure that produces descriptive data in the form of written or oral words from people and observable behavior (Moleong, 2007).

This study used a qualitative research method with a phenomenological approach on the grounds that the focus in this research is the profit sharing model for brown sugar farmers. Meanwhile, the phenomenological approach aims to describe the meaning of life experiences experienced by some individuals about certain concepts or phenomena by exploring the structure of human consciousness. So, here the researcher wants to find out the meaning of the experience experienced by the brown sugar farmers related to the sharing 
JARES, Vol. 4 No. 2 September, 2019; p-ISSN: 2502-826X; e-ISSN: 2503-1163

Copyrights@ Balitar Islamic University, Blitar, Indonesia;

https://ejournal.unisbablitar.ac.id/index.php/jares

Citation: Elvianita Martanti, D., \& Suprayitno , H. (2019). NDERES PROFIT SHARING MODEL ON THE BROWN SUGAR FARMERS IN NGLEGOK DISTRICT BLITAR REGENCY. JARES (Journal of Academic Research and Sciences), 4(2), 39-50. https://doi.org/10.35457/jares.v4i2.841 model for nderes through this phenomenological study.

Phenomenology seeks to express, study and understand a phenomenon of unique context and unique context experienced by individuals to the level of "belief" of the individual concerned. By studying and understanding it must be based on the perspective, paradigm, and direct beliefs from the individual concerned as the subject who experiences directly (first-hand experiences). In other words, the phenomenological approach seeks to search for the psychological meaning of an individual's experience of a phenomenon through in-depth research in the daily life context of the subject researched (Herdiansyah, 2012).

The focus of the phenomenological approach model is the experiences experienced by individuals. How individuals interpret their experiences related to certain phenomena that are very meaningful to the individual concerned. The experiences discussed here are not just ordinary experiences, but experiences related to the structure and level of individual awareness directly or indirectly. Therefore, the phenomenological approach model focuses on the personal experiences of individuals, the research subjects are people who have experienced events or phenomena that occur, not individuals who only know a phenomenon indirectly or through certain media (Fauzan and Ghony, 2012: 59).

The subject of this research is the Calculation of Nderes Profit Sharing System of Brown Sugar Farmers (Phenomenology Study of Brown Sugar Farmers). Subjects were chosen purposively based on their activities and their willingness to explore and articulate their experience in determining the prices they marketed with the nderes method. The research subjects were made the main informants or the main data sources.

The object of this research being studied or aspects that become facts of research is about the meaning of nderes profit sharing results. The question of this research is: How do brown sugar farmers interpret the determination of nderes profit sharing.

\section{RESULTS AND DISCUSSION}

Life community is a social study that is not exhausted to be discussed, both economically, socially and culturally. Likewise in this research, one of the community 
JARES, Vol. 4 No. 2 September, 2019; p-ISSN: 2502-826X; e-ISSN: 2503-1163

Copyrights@ Balitar Islamic University, Blitar, Indonesia;

https://ejournal.unisbablitar.ac.id/index.php/jares

Citation: Elvianita Martanti, D., \& Suprayitno , H. (2019). NDERES PROFIT SHARING MODEL ON THE BROWN SUGAR FARMERS IN NGLEGOK DISTRICT BLITAR REGENCY. JARES (Journal of Academic Research and Sciences), 4(2), 39-50. https://doi.org/10.35457/jares.v4i2.841 economics study in Blitar District was brown sugar farmers in Sanan Dayu, Nglegok

District, Blitar Regency.

The income of brown sugar farmers in Sanan Dayu Village is determined by several factors including the number of trees and production costs, as well as the method of cooperation that can determine the income of brown sugar farmers. This is consistent with the results of research by Siti Khotimah et al (2014: 52) which states that one of the factors affecting the income of brown sugar farmers is the profit sharing system or cooperation between coconut tree owners and penderes or climber. The results of his research also state that the income of the residents in the system for the sharing of brown sugar is higher than the income of the residents with the profit sharing system. This means that the income of the owner of a coconut tree in the sugar-sharing system (ounces) is less than the income with the profit sharing of tampan(tumbler).

The process of producing brown sugar in Sanan Dayu has 2 stages. First, the stage of taking extract coconut water and the second stage of processing extract coconut water into brown sugar. At the stage of taking extract coconut water is usually done twice a day, namely in the morning and evening. In the morning the penderes or climber take extract coconut water while in the afternoon it is only for cutting flowers or coconut milk. The purpose of cutting "mayang" the flower of coconut so that the results of the extract coconut water obtained more or better. If cutting the flowers of coconut is only done in once a day, the flowers of coconut milk will dry up so that the extract palm water become less.

After the process of taking extract coconut water is finished, the next step is processing the extract coconut water into brown sugar. To convert extract coconut water into brown sugar, it must be boiled for about 4 to 5 hours until it thickens. The stages in the treatment of extract coconut water are:

a. Provide a container for cooking extract coconut water and place it on the stove. The container used is usually a large skillet or can also use "kenceng".

b. The extract coconut water that has been previously stored in the tub is poured into a container that has been provided while filtered so that the excretion do not come cooked.

c. Furthermore, heat the stove with firewood and boil until the extract coconut water shrinks, and turns brownish red. If the extract coconut water is almost boiling and lumps 
JARES, Vol. 4 No. 2 September, 2019; p-ISSN: 2502-826X; e-ISSN: 2503-1163

Copyrights@ Balitar Islamic University, Blitar, Indonesia;

https://ejournal.unisbablitar.ac.id/index.php/jares

Citation: Elvianita Martanti, D., \& Suprayitno , H. (2019). NDERES PROFIT SHARING MODEL ON THE BROWN SUGAR FARMERS IN NGLEGOK DISTRICT BLITAR REGENCY. JARES

(Journal of Academic Research and Sciences), 4(2), 39-50. https://doi.org/10.35457/jares.v4i2.841 of foam have begun to appear on the surface, then pour the grated coconut until it boils so that the water does not burst.

d. After the extract coconut water shrinks, changes color and thickens lift the container from the furnace and then stir it and "dicicek". "Dicicek" means rubbing the liquid sugar around the edge of the container using wood to make it thicker and harden quickly. After that, pour the liquid brown sugar into the coconut shell container that has been provided and wait for it until harden and easily be removed from the mold and brown sugar is ready to be marketed.

According to Anis (2018: 50), tampan is a Javanese term that comes from the word tompo. Tompo in Indonesian means accept. In the production of brown sugar, tompo means receiving extract coconut water from the yield of coconut trees that will be processed into brown sugar in accordance with the agreement between the owner of the coconut tree and the penderes or climber.

In the production of brown sugar, tampan is a method of cooperation involving between the owner of a coconut tree and a penderes or climber that the purpose is to obtain mutual benefits. Coconut tree owners who are unable to collect extract coconut water themselves can work together with penderes so that coconut tree owners can process extract coconut water into brown sugar. As for penderes, even though they do not have coconut trees, they can produce brown sugar using tampan methods. This will certainly be beneficial for both parties because with this cooperation they will get more income. The income received by the brown sugar farmers by the tampan method between the owners of coconut trees and the amount of penderes will be different. This depends on the tampan method used. So, the tampan method is one of the profit sharing methods used by brown sugar farmers between coconut tree owners and penderes in Sanan Dayu Nglegok District, Blitar Regency with profit sharing in the form of extract coconut water which is the raw material for brown sugar. In the tampan method, penderes will take the extract coconut water from the the tree owner and the extract coconut water will be divided with the coconut tree owners based on the agreement.

Generally, the agreement for the distribution of extract coconut water in Sanan Dayu is $7: 7$ it means that the dwellers receive the extract coconut water for 7 days and the owner of the coconut tree receives extract coconut water for 7 days also alternately. But now the 
JARES, Vol. 4 No. 2 September, 2019; p-ISSN: 2502-826X; e-ISSN: 2503-1163

Copyrights@ Balitar Islamic University, Blitar, Indonesia;

https://ejournal.unisbablitar.ac.id/index.php/jares

Citation: Elvianita Martanti, D., \& Suprayitno , H. (2019). NDERES PROFIT SHARING MODEL ON THE BROWN SUGAR FARMERS IN NGLEGOK DISTRICT BLITAR REGENCY. JARES (Journal of Academic Research and Sciences), 4(2), 39-50. https://doi.org/10.35457/jares.v4i2.841 agreement for the distribution of extract coconut water has begun to change to 10: 7 and 7:

6. This means that the penderes get extract coconut water for 10 days while the coconut tree owner only gets sap water for 7 days or the penderes get extract coconut water for 7 days while the coconut tree owner only gets extract coconut water for 6 days. This is because to find the penderes has begun to be difficult so that the authority for the distribution of extract coconut water is left to the penderes.

In tampan 7: 7 although the distribution of water is the same, but their income is different because the costs incurred are also different. This is similar to the results of a study conducted by Ansyar (2014: 54) which states that there are differences in net income from coconut sugar production between coconut tree owners and penderes. The owner of a coconut tree receives a greater than penderes because the costs incurred by penderes are greater than the owner of the coconut tree.

The difference distribution of extract coconut water by tampan method will surely make the income of the coconut tree owners and penderes different. The more extract coconut water that is obtained, the greater income that will be received both for the owner of the coconut tree and penderes. Vice versa, the less water we get, the less income will be received.

Another factor that distinguishes income between coconut tree owners and penderes is the costs incurred. This is due to differences in duties between coconut tree owners and penderes. In the tampan method, the owner of a coconut tree only handle the pocess of extract coconut water, while for the penderes besides processing extract coconut water also has to take extract coconut water and the equipment to collect extract coconut water must be borne by the penderes himself. This is what makes the income difference between coconut tree owners and penderes.

The following is the concept of the profit sharing model for brown sugar production. 
JARES, Vol. 4 No. 2 September, 2019; p-ISSN: 2502-826X; e-ISSN: 2503-1163

Copyrights@ Balitar Islamic University, Blitar, Indonesia;

https://ejournal.unisbablitar.ac.id/index.php/jares

Citation: Elvianita Martanti, D., \& Suprayitno , H. (2019). NDERES PROFIT SHARING MODEL ON THE BROWN SUGAR FARMERS IN NGLEGOK DISTRICT BLITAR REGENCY. JARES (Journal of Academic Research and Sciences), 4(2), 39-50. https://doi.org/10.35457/jares.v4i2.841

7 Hari

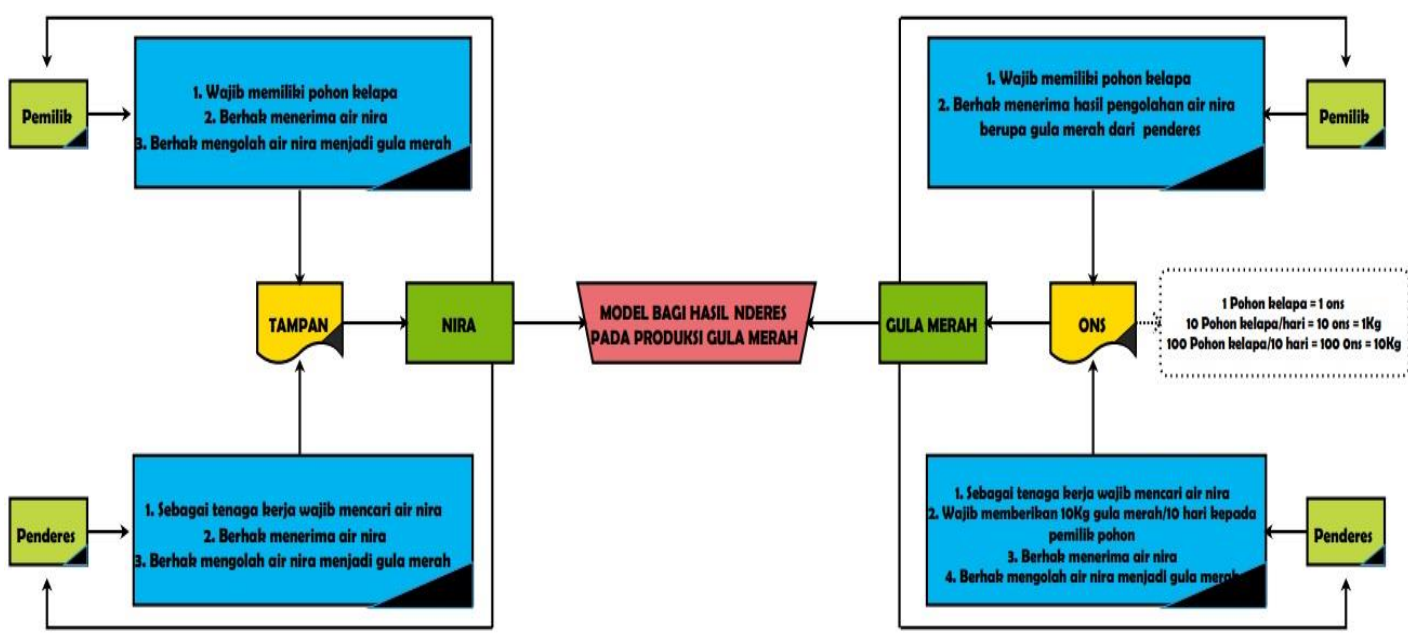

7 Hari

There are 2 profit sharing models in brown sugar production in Sanan Dayu, there are 2 models, namely the tampan profit sharing model and the ounce profit sharing model. In a tampan profit-sharing model involving coconut tree owners and penderes. The responsibility of the owner if using a tampan profit-sharing model includes the owner must have a coconut tree, getting extract coconut water and procesings it into brown sugar. Whereas the responsibility of the penderes when using a tampan profit-sharing model includes the compulsory search for extract coconut water because the person serves as the laborer, he has the right to take extract coconut water and process extract coconut water into brown sugar. This tampan profit-sharing model yields an agreement that the profit sharing will be in the form of extract coconut water in which the revenue sharing system is 7: 7. That is, the penderes receives extract coconut water for 7 days and for the next 7 days it is received by the owner of the coconut tree.

Meanwhile, the ounce profit sharing model is the same as the tampan profit sharing model involving coconut tree owners and penderes. The responsibility of the owner if using the ounce production sharing model includes the owner must have a coconut tree and be entitled to receive the results of extract coconut water treatment in the form of brown sugar from the penderes. Whereas the responsibility of the penderes when using the ounce profit sharing model includes the penderes required to take extract coconut water because the penderes act as laborers, must provide $10 \mathrm{~kg}$ of brown sugar / 10 days to the tree owners, 
JARES, Vol. 4 No. 2 September, 2019; p-ISSN: 2502-826X; e-ISSN: 2503-1163

Copyrights@ Balitar Islamic University, Blitar, Indonesia;

https://ejournal.unisbablitar.ac.id/index.php/jares

Citation: Elvianita Martanti, D., \& Suprayitno , H. (2019). NDERES PROFIT SHARING MODEL ON THE BROWN SUGAR FARMERS IN NGLEGOK DISTRICT BLITAR REGENCY. JARES (Journal of Academic Research and Sciences), 4(2), 39-50. https://doi.org/10.35457/jares.v4i2.841 they have the right to receive extract coconut water and have to process extract coconut water into brown sugar. This ounce profit sharing model results in an agreement that the revenue share is brown sugar in which the revenue sharing system for tree owners is given within 10 days. That is, every 1 tree is equal to 1 ounce of brown sugar. If one day the processed yield is sourced from 10 coconut trees, then a day reaches $1 \mathrm{~kg}$ of brown sugar. So, in 10 days with the results of 100 coconut trees that are processed will produce as much as $10 \mathrm{~kg}$ of brown sugar. So, in 10 days the tree owner will get a profit sharing of $10 \mathrm{~kg}$ of brown sugar. For the remainder of the extract coconut water can be owned by the penderes.

\section{CONCLUSION}

From the explanation of the results and discussion above, the profit sharing model in the District of Nglegok, Blitar Regency.

1. Emphasis on the family concept with "mlaku bareng" and "podo mangan bareng" which means walking together and eating together no one is harmed by the collaboration.

2. The tampan profit-sharing model involves coconut tree owners and penderes. The responsibility of the owner if using a tampan profit-sharing model includes the owner must have a coconut tree, the right to get extract coconut water and the right to process it into brown sugar. Whereas the responsibility of the penderes when using a tampan profitsharing model includes the compulsory search for extract coconut water because the person serves as the laborer, has the right to obtain extract coconut water and has the right to process it into brown sugar. This tampan profit-sharing model yields an agreement that the profit sharing will be in the form of extract coconut water in which the revenue sharing system is 7: 7. That is, the penderes receives extract coconut water for 7 days and for the next 7 days it is received by the owner of the coconut tree. Meanwhile, the ounce profit sharing model is the same as the tampan profit sharing model involving coconut tree owners and penderes. The responsibility of the owner if using the ounce production sharing model includes the owner must have a coconut tree and be entitled to receive the results of coconut water treatment in the form of brown sugar from the penderes. Whereas the responsibility of the penderes when using the ounce profit sharing model includes the penderes required to search for extract coconut water because the penderes 
JARES, Vol. 4 No. 2 September, 2019; p-ISSN: 2502-826X; e-ISSN: 2503-1163

Copyrights@ Balitar Islamic University, Blitar, Indonesia;

https://ejournal.unisbablitar.ac.id/index.php/jares

Citation: Elvianita Martanti, D., \& Suprayitno , H. (2019). NDERES PROFIT SHARING MODEL ON THE BROWN SUGAR FARMERS IN NGLEGOK DISTRICT BLITAR REGENCY. JARES (Journal of Academic Research and Sciences), 4(2), 39-50. https://doi.org/10.35457/jares.v4i2.841 act as laborers, must provide $10 \mathrm{~kg}$ of brown sugar / 10 days to tree owners, have the right to receive extract coconut water and have the right to process it into brown sugar.

3. This ounce profit sharing model results in an agreement that the revenue share is brown sugar in which the revenue sharing system for tree owners is given within 10 days. That is, every 1 tree is equal to 1 ounce of brown sugar. If one day the processed yield is sourced from 10 coconut trees, then a day reaches $1 \mathrm{~kg}$ of brown sugar. So, in 10 days with the results of 100 coconut trees that are processed will produce as much as $10 \mathrm{~kg}$ of brown sugar. So, in 10 days the tree owner will get a profit sharing of $10 \mathrm{~kg}$ of brown sugar. For the remainder of the extract coconut water can be owned by the penderes.

\section{ACKNOWLEDGMENTS}

Thank you to all who helped this research, the Dean of the Economics Faculty at Balitar Islamic University, who gave permission for this research. The Nglegok people who gave their time to become informants, I said thank you, and the DPRM Simlitabmas which has provided 2019 PDP research funding.

\section{REFERENCES}

Anis, Mochammad. 2018. Analisis Pendapatan Produksi Gula Merah Skala Rumah Tangga Dengan Metode "Tampan”. Skripsi: Fakultas Ekonomi Universitas Islam Balitar.

Ansyar, Afriyanti. 2014. Analisis Perbedaan Pendapatan Petani Pemilik Penggarap Dan Petani Penggarap Pada Usaha Gula Kelapa Desa Purbosari Kecamatan Seluma Barat Kabupaten Seluma. Skripsi: Fakultas Ekonomi Universitas Bengkulu.

Fauzan, Almanshur. Ghony, Djunaidi. 2012. Metodologi Penelitian Kualitatif. Jogyakarta : Ar-Ruzz Media.

Herdiansyah, Haris. 2012. Metodologi Penelitian Kualitatif Untuk Ilmu-Ilmu Sosial. Jakarta Selatan : Salemba Humanika.

Irmayanti. 2010. Sistem Bagi Hasil Antara Pemilik Lahan Dengan Petani Penggarap Usaha Tani Lahan Sawah Di Desa Bontotallasa Kecamatan Simbang Kabupaten Maros. Skripsi: Fakultas Pertanian Universitas Hasanudin.

Jusmaliani. Muhammad Soekarni, Ed. 2005. Kebijakan Ekonomi Dalam Islam. Yogyakarta : Kreasi Wacana.

Khotimah, Siti dkk. 2014. Analisis Pendapatan Pengrajin Gula Kelapa Dan Kontribusinya Terhadap Pendapatan Keluarga Di Desa Lojejer Kecamatan Wuluhan Kabupaten Jember. JSEP Vol.7 No.2 Hal. 45-54. 
JARES, Vol. 4 No. 2 September, 2019; p-ISSN: 2502-826X; e-ISSN: 2503-1163

Copyrights@ Balitar Islamic University, Blitar, Indonesia;

https://ejournal.unisbablitar.ac.id/index.php/jares

Citation: Elvianita Martanti, D., \& Suprayitno , H. (2019). NDERES PROFIT SHARING MODEL ON THE BROWN SUGAR FARMERS IN NGLEGOK DISTRICT BLITAR REGENCY. JARES

(Journal of Academic Research and Sciences), 4(2), 39-50. https://doi.org/10.35457/jares.v4i2.841

Moleong, Lexy J. 2007. Metodologi Penelitian Kualitatif. Bandung : Remaja Rosdakarya.

Sugiyono. 2009. Metode Penelitian Bisnis (Pendekatan Kuantitatif, Kualitatif, dan R\&D). Bandung : Alfabeta.

Wahyuningsih, Tri. 2011. Sistem Bagi Hasil Maro Sebagai Upaya Mewujudkan Solidaritas Masyarakat. Jurnal Komunikasi, Vo;3 No. 02.

Hidayat, L., Huda, A. M., \& Mauliyah, N. (2019). Model Kerjasama Bagi Hasil Dengan Metode "Kedok" Pada Petani Padi Pemilik Dan Petani Padi Penggarap (Studi Kasus Pada Petani Padi Pekon Mulyorejo Kecamatan Banyumas Kabupaten Pringsewu), 3(1).

Huda, A. M., \& Martanti, D. E. (2018). Pengantar Manajemen Strategik 1. (J. Press, Ed.) (1st ed.). Bali: http://books.jayapanguspress.org/index.php/publisher/article/view/18/18. Retrieved from http://books.jayapanguspress.org/index.php/publisher/article/view/18/18

Mauliyah, M., Masrunik, E., \& Wahyudi, A. (2017). Model Transaksi “Kenceng Jreng” Danmodel "Saur Gowo" Pada Jual Beli Sayuran Di Kabupaten Blitar Oleh:, 2. 